American Research Journal of Humanities and Social Sciences

(ARJHSS)

ISSN (Online) : 2378-7031

Volume 2, 2016, 1-4 pages

DOI: 10.21694/2378-7031.16011

\title{
Research Investigation and Analysis of Moral Leadership
}

\section{Issues}

\author{
Abdulaziz Alsolmi \\ Saint Louis University, United States \\ alsolmias@slu.edu
}

\begin{abstract}
There are many ways that experts can help educators to improve education system in order to have suitable education for every individual. Parents always try hard to help their students when they cooperate with school district to establish good educational standards. So, board of education always comes with new rules in order to make safe environment as well as great place to improve academic performance. Because education is for every individual in the society, legislature mandated some rules to guarantee education for everyone include students with special needs. More importantly, effective leaders have the ability to change for better in educational environment. Also, their knowledge and characteristics help them to overcome potential obstacles and prepare workers to achieve their proposed objective goals.
\end{abstract}

\section{INTRODUCTION}

There are many way that people may reach to their dream and achieve their effective goal. Many people complain from poor achievement because their plans lack the main and basic principles that lead to proper achievement. As leaders, motivation always plays strong role for people to get what they plan to do. It becomes more significantly when those motivations are moral and ethics. Furthermore, moral and ethical leaders can come with great outcomes because they have power toll that taps on people dignity. In this paper, I will discuss the importance of ethics and educational leadership and the impact of improvement in different educational filed.

\section{THE MEANING OF ETHICS}

Ethics and moral are two main important terminologies that always help leaders to get their proposal goal. Being a moral or ethical leader has huge impact for leaders when they behave in their life. According to Ciulla (2003), ethical leaders usually have the same attitude toward some issues because they deal and analyze issues based on ethical prospective. More importantly, moral and ethical leaders have many followers because people like to work with a leader who basically behaves ethically on all his or her work. Thus, followers will not find it hard to know more about their ethical leaders and their way of thinking for different issues. So, it is really meaningful when people who work with you know your behavior and expect your action in some cases.

\section{SOME DESCRIPTION OF ETHICAL LEADERS}

Leaders are different in their thinking on how they can achieve their goal or win on their enemies in the competition's field. Some leaders believe that they are the victory maker and they become proud and become selfish with others because they are arrogance and they lack of ethics. In contrast, ethical and moral leaders do not think or believe that they are the only victory or successful makers. According to Ciulla (2003) ethical leaders always put people first and try to engage all workers together because that know that success can not depend on small group of people. In addition, sharing knowledge and work as a team are significantly strategies that usually lead to great success and outcomes (Fullan, 2007). 
Ethical leaders achieve success because they won people's heart before start get their hands. Ethical and moral leaders should have prepared with some unique characters that distinguish them between other leaders. Generosity is one of the most important feature that help leaders to get more followers in different field (johnson, 2009). Also, generous leaders like to help their workers because they believe that put people needs first. Being a generous leader helps followers to work with you because followers know that they would get what they need. Moreover, sharing knowledge and working as a team are tremendous because all individuals inside the team become united and they feel that they are partner in the success regardless of each individual basic role (Bolman \& Deal, 2008). Their internal motivation will guide them to work hardly in order to achieve their goal because they feel that they have important role in such success.

\section{VISIONARY LEADERSHIP}

A visionary leader is very clear about his or her ideas and plans. He or she knows what best for students- for their academic, social and emotional learning (Fullan, 2007). Also, the leader's great beliefs have developed in involvement and engagement with other stakeholders onto some type of vision and mission statement. Thus, this visionary leadership will ease barriers for leaders and their followers to achieve their planned goals.

\section{DETERMINATION OF BARRIERS AND THEIR SOLVES}

According to previous studies, there are many factors behind the successful of inclusion process in the field of education for students with special needs. The main barriers, which many teachers suffer from when they attempt to include special education students in general setting, represented in three main points. First, both educators and school personnel suffer from the lack of training in the field of inclusive education (Conroy, 2011). This absence of employee professional development leads many teachers and school personnel to be unaware of dealing with impaired students. Also, some teachers have tried hardly to be more productive and creative to adopt new strategies to help this group of students.

Second, many teachers have stated that one of the biggest factors impeded the meaningful of inclusion is the shortage of resources. According to Kuzub (2002), large and small schools' districts complain from the lack of reasonable and adapted equipment because of the budget restriction. So, the shortage of adapted equipment goes further than the inclusion by affecting educational system of students with special needs. For example, when schools do not provide the students with needed tools that mean educational and inclusion will not be applied. Special education students need assistive devices in order to help them to tackle with their peers during the educational process in the classrooms. Lack of devices leads teachers to spend long time on creating reasonable equipment that help their students to study.

Finally, many teachers stated that they do not have enough time to teach students who have difficulties. Time management is a major problem when teachers try to present effective teaching for those students (Kuzob, 2002). Also, time with the student on an individual basis is crucially important in order to pre-teach some new skills and concepts (Conroy, 2011). Therefore, teachers of students with special needs require more time when they adapt new equipment or teach new skills.

\section{EMPLOYEES' DEVELOPMENT}

The field of education is one of the most important field that needs ongoing improvement and development. According to yell (2012) education should be provided for each individual in our society. Ethical educational leaders will concentrate on people attitude toward change because it is very important to change people's mindset. So, hard effort should take place in order to deliver suitable education for our children. Ethical educational leaders will present great education because they have the ability to change people attitude toward better change (Johnson, 2009). 
They always tapping on people dignity and encourage people to feel that they are able to make improvement (Bolman \& Deal, 2008). In addition, getting best and knowledgeable people always make big improvement because they are experts in their areas. Dividing missions on specialized people will save the time and make big progress in the field of education. Ethical educational leaders will improve their employee with needed developmental courses in order to be more qualified in the educational environment. Also, effective leaders will provide their employee with individualized support as well as appropriate models of best practice (Ciulla, 2003).

\section{MEANINGFUL CHANGE TOWARD BETTERMENT}

Leaders need to be brave in order take some difficult action toward valuable change (Johnson, 2009). Successful change is knowing that all effective approaches are socially based and action oriented, both of which change by performance rather than by making plans (Fullan, 2007). This strategy will show its vision about change by acting it out. It demonstrates the importance of the action by starting to immediately work on what we want to achieve. One of the main important elements is to strengthen social relationships, which lead to more trust as well as stimulating collaboration (Fullan, 2007). Also, gaining individuals' confidence needs various types of actions such as getting involved in conversation, completing admired work, showing respect while communicating and signifying the inclusion of others (Fullan, 2007).

A socially based solution is very important to reach people's motivation and feelings. "Fostering professional learning communities should include forums for teachers to collectively reflect on and collaborate on the ethnic and moral dimensions of their work and behavior" (Fullan, 2007). Cooperating, and working as a group, is essential to improve our environmental work as well as our behavior. Furthermore, organizations should involve and support all members to be involved, as well as show them empathy when they are in difficult circumstances. Establishment leaders, who need to apply a reliable change, must leave their own fantasy and find the best way of making the change in their school culture (Reeve, 2006). So, barriers between the leaders and their colleagues should be removed in order to grant them satisfaction and motivate them to be more productive.

The third component of successful change is to confirm that best employees should be appointed for difficulties. According to their distinct qualifications, which associated with their cumulative experiences, brilliant employees are usually appointed to solve the problems that happen in jobs (Fullan, 2007). Talented principals and leaders are always wanted because they know exactly how to work on problems as well as show their ability of dealing with hard circumstances. Because of the raised problems and challenges, the demand of experts to solve such situation is very important (Fullan, 2007).

\section{CONCLUSION}

To sum up, leadership plays strong role in achieving success and improvement. Ethical leaders promise them selves and their followers to present great development to their communities. Moreover, effective leaders will have the ability to diagnose real problems in our educational environment as well as they promise to come with effective strategies to solve those problems. Furthermore, effective leaders prepare them selves to face expected and unexpected crisis in their field. They work hard with other experts to bring deserved improvement in our education for all students.

Volume 2

Page 3 


\section{REFERENCES}

Bolman, L. G. \& Deal, T. E. (2008) Reframing organizations: Artistry, choice, and leadership. (4 th $^{\text {ed.) San }}$ Francisco: Jossey-Bass. ISBN:978-0-7879-2.

Correa, S., \& Durando,J. (2011). Perceived training needs of teachers of students with visual impairments who work with students from culturally and linguistically diverse background. CEU, 521-532.

Craig E. Johnson (2009), Meeting the Ethical Challenges of Leadership. 5th edition. Thousand Oaks, California: Sage Publications, 2009. ISBN 978-1412964814

Ciulla, Joanne B (2003). The Ethics of Leadership. Thomson/Wadsworth.

ISBN:0155063170

Fullan, M. (2007). THE NEW MEANING OF EDUCATIONAL CHANGE. (4 ${ }^{\mathrm{TH}}$ ed.). New York: Teacher College Press. ISBN:987-0-8077-4765-0

Kozub, F. (2002). Perceved barriers to including students with visual impairments in general physical education. Adapted Physical Activity Quarterly, 364-377.

Reed, M., \& Curtis, K. (2011). High school teachers' perspective on supporting students with visual impairments toward higher education: access, barriers, and success. CEU, 458-559.

Yell, M. L. (2012). THE LAW and SPECIAL EDUCATION . Upper Saddle River: Pearson.

Citation: Abdulaziz Alsolmi, Research investigation and analysis of moral leadership issues. American Research Journal of Humanities and Social Sciences, Volume 2, 2016; pp:1-4

Copyright (c) 2016 Abdulaziz Alsolmi, This is an open access article distributed under the Creative Commons Attribution License, which permits unrestricted use, distribution, and reproduction in any medium, provided the original work is properly cited. 